\title{
Status and Management of Roseate Terns (Sterna dougallii) in Nova Scotia
}

\author{
MARTY LEONARD ${ }^{1 *}$, ANDREW BOYNE ${ }^{2}$ and SHERMAN BOATES ${ }^{3}$ \\ ${ }^{1}$ Department of Biology, Dalhousie University, \\ Halifax, Nova Scotia, B3H 4J1 \\ ${ }^{2}$ Canadian Wildlife Service, Environment Canada, \\ Dartmouth, Nova Scotia, E4L 1 G6 \\ ${ }^{3}$ Nova Scotia Department of Natural Resources, \\ Kentville, Nova Scotia, B4N 4E5
}

\begin{abstract}
The most important breeding colonies for endangered roseate terns in Canada occur on coastal islands in Nova Scotia. The main threat to productivity at these sites appears to be predation, particularly from gulls. The goal of this paper is twofold: 1) to present the results of recent roseate tern surveys in Nova Scotia and 2) to report on the results of a non-lethal gull control program at one of the main breeding sites in the province. The results of the surveys suggest that the number of breeding pairs (approximately 130) in the province has remained relatively stable, and is similar to numbers reported 20 years ago. Breeding sites have, however, fluctuated in number from a high of 10 sites in 1999 to a low of 3 in 2003. Although the concentration of birds to few locations makes some management options easier, it also increases their vulnerability to chance events. The non-lethal gull control program initiated on Country Island in 1998 has proven relatively successful, resulting in an increase in the numbers of breeding common, arctic and roseate terns on the island and a decrease in predation of tern eggs and chicks. Although this program has been effective in reducing predation, it must be maintained in the long-term if these birds are to breed successfully.
\end{abstract}

Au Canada, les plus grosses colonies de Sternes de Dougall, espèce en voie de disparition au pays, se trouvent sur des îles côtières de la Nouvelle-Écosse. La principale menace à la productivité de ces colonies semble être la prédation, en particulier par les goélands et les mouettes. Le présent document vise deux objectifs : 1) présenter les résultats des récents relevés de Sternes de Dougall en Nouvelle-Écosse et 2) faire état des résultats d'un programme de lutte non mortel contre les goélands et les mouettes mis en œuvre dans un des principaux lieux de nidification de la province. Selon les relevés, le nombre de couples nicheurs (environ 130) est demeuré relativement stable dans la province et est comparable à celui signalé il y a 20 ans. Cependant, le nombre de lieux de nidification a varié, passant de 10 lieux en 1999 à 3 en 2003. La concentration des oiseaux en seulement quelques endroits peut faciliter l'application de certaines méthodes de gestion, mais elle rend plus vulnérables aux phénomènes stochastiques. Le programme de lutte non mortel contre les goélands et les mouettes mis en œuvre en 1998 dans l'île Country a assez bien réussi et y a entraîné l'augmentation du nombre de Sternes pierregarins, de Sternes arctiques et de Sternes de Dougall nicheuses et une réduction de la prédation des œufs et des poussins de sternes. Bien que le programme ait contribué à diminuer la prédation, il faut le maintenir à long terme pour que les oiseaux puissent se reproduire.

\section{General Introduction}

Roseate terns breed on coastal islands across six continents. In North America they nest in two distinct areas ranging from the Magdalen Islands to New York and from Florida to the Lesser Antilles (Gochfeld et al. 1998). About 3\% of the North American population breeds in Canada, with $95 \%$ of these individuals restricted to a few islands in Nova Scotia (Whittam 1998).

In 1986, the Committee on the Status of Endangered Wildlife in Canada (COSEWIC) designated roseate terns as threatened (Kirkham \& Nettleship 1985). This designation was based partially on the observed decline in the northeastern U.S. from about 4,800 pairs in 1972 to 2,600 pairs in 1976 (Kress et al. 1983) and on a corresponding decline on Sable Island, Nova Scotia from an estimated 130 pairs in 1971 to 18 birds in 1976

* Author to whom correspondence should be addressed 
(Kirkham \& Nettleship 1985). Using new criteria developed by COSEWIC, the species has since been reclassified as endangered (Whittam 1998), because its small numbers and restricted distribution make it vulnerable to a variety of environmental threats.

In Nova Scotia the main threat to roseate tern productivity appears to be predation (D'Eon 1998, Whittam \& Leonard 1999). Indeed, predation of roseate eggs and chicks by avian predators resulted in the abandonment of Country Island, one of Nova Scotia's most important breeding sites, in 1997 (see below; Whittam \& Leonard 1999). Thus, it would appear that the fate of the majority of Canada's roseate terns depends on how predators are managed at critical breeding colonies in Nova Scotia.

The goal of this paper is to highlight some of the work being conducted in Nova Scotia to protect this endangered species. We divide the paper into two sections. In the first section, we provide information on the size and distribution of Nova Scotia's roseate tern population during the last 20 years. In the second section, we report on the results of a non-lethal predator control program initiated on Country Island in 1998.

\section{Population Size and Distribution of Roseate Terns in Nova Scotia}

\section{Introduction}

Roseate terns have never been common in Nova Scotia, however there is some evidence that the species was more numerous in the first half of the last century (Tufts 1962). Although specific numbers are not provided, there appear to have been a number of roseate terns on Sable Island from 1894 to 1907, and a large colony on Noddy Island in 1906 (Kirkham \& Nettleship 1985). About 125 pairs were also reported on Indian Island, Lunenburg County in 1930 (Tufts 1962). By 1970-71, approximately 200 pairs of roseate terns nested at six sites in the province (Sable Island, 130 pairs; Hobson's Nose Island, 28 individuals; Wedge Island, 45 pairs; Tusket Island, present; and an unnamed islet between Calf and Low Islands, 15 individuals), and were believed to have nested on an unnamed island in Boutillier Bay near Spry Point (Lock 1971). Surveys conducted between 1982 and 1985 indicated that between 100 and 120 pairs of roseate terns nested in the province. Thus, most historical information suggests that a relatively stable population of roseate terns, ranging from 100 to 200 pairs, nested in Nova Scotia during the previous century.

Below we report on the results of three intensive surveys conducted in 1995, 1999 and 2003 to locate and count roseate terns in Nova Scotia. For comparison, we also provide the number and distribution of roseate terns located during the only other intensive survey of the province that occurred between 1982 and 1985.

\section{Methods}

Tern colonies were identified during aerial surveys of the coastline of Nova Scotia in the summers of 1995, 1999 and 2003. Roughly, 60\% of the coastline of the province was surveyed in all three years by the same observer. The survey track was recorded in 1995 using a Garmin ${ }^{\text {TM }}$ PCX5 AVD global positioning system, so that the same route could be surveyed in subsequent years. Colonies estimated from the air to contain over 100 terns were visited on the ground because roseates generally nest in larger colonies of arctic (S. paradisaea) and common (S. hirundo) terns. Sable Island was only surveyed by ground.

\section{Results and Discussion}

A total of 96 pairs of roseate terns were counted at five sites in Nova Scotia in 1995, 119-143 pairs at 10 sites in 1999, and 130 pairs at three sites in 2003 (Table 1). Annual 
Table 1 Estimated number and location of roseate tern pairs recorded during surveys of Nova Scotia in 1982-85, 1995, 1999 and 2003.

\begin{tabular}{lllllll}
\hline Site & Latitude & Longitude & $\mathbf{1 9 8 2 - 8 5}^{\mathbf{1}}$ & $\mathbf{1 9 9 5}^{\mathbf{2}}$ & $\mathbf{1 9 9 9}^{\mathbf{3}}$ & $\mathbf{2 0 0 3}^{\mathbf{3 , 4}}$ \\
\hline Peter Island & 44.258 & -66.339 & 1 & 1 & 2 & - \\
Tusket Island & 43.650 & -66.033 & $15-20$ & $0^{*}$ & - & $0^{*}$ \\
Mud Island & 43.474 & -65.987 & 2 & $\mathrm{x}$ & $\mathrm{x}$ & $\mathrm{x}$ \\
The Brothers & 43.633 & -65.825 & $55-60$ & 33 & 61 & 86 \\
Salmon Island & 43.417 & -65.633 & - & - & 16 & 0 \\
McNutt's Island & 43.633 & -65.283 & - & $0^{*}$ & $1-2$ & 0 \\
Hughes Island & 43.733 & -65.017 & - & $0^{*}$ & $5-10$ & 0 \\
Westhaver Island & 44.436 & -64.338 & 8 & $0^{*}$ & present & 0 \\
Mash Island & 44.400 & -64.233 & - & - & $10-20$ & 0 \\
Grassy Island & 44.750 & -64.217 & - & 30 & $0^{*}$ & 0 \\
Wedge Island & 44.610 & -63.948 & 6 & $0^{*}$ & $5-10$ & - \\
Macdonald Point & 44.617 & -63.933 & - & - & $3-6$ & - \\
Sambro Island & 44.437 & -63.563 & 3 & $0^{*}$ & - & $0^{*}$ \\
Fisherman's Beach & 44.667 & -63.217 & present & - & - & - \\
Lobster Island & 44.910 & -62.303 & - & - & 0 & 1 \\
Thrumcap Island & 44.957 & -62.040 & present & $0^{*}$ & - & - \\
Country Island & 45.067 & -61.533 & - & 30 & 16 & 43 \\
Sable Island & 43.950 & -59.917 & $10-20$ & 2 & $\times$ & $\mathrm{x}$ \\
\hline & & Total pairs & $100-120$ & 96 & $119-143$ & 130 \\
& & Colonies & 10 & 5 & 10 & 3 \\
\hline
\end{tabular}

${ }^{1}$ Kirkham \& Nettleship 1985, ${ }^{2}$ Boates 1995, ${ }^{3}$ Boyne 1999, 2003, ${ }^{4}$ D'Eon, 2003. $0=$ colony visited, but roseate terns not observed, $0^{*}=$ tern colony present, but $<100$ terns, so colony not visited, - = island surveyed from the air, but no tern colony, $\mathrm{x}=$ island not surveyed from air or ground

counts between 2000 and 2002 at Country Island and the Brothers reported a total of 131, 71 and 139 pairs of roseates in each year, respectively. Based on the complete survey of the province conducted in 2003 it appears that the large number of roseates nesting on Country Island and The Brothers from 2000 to 2002 represented a contraction of existing birds into a few large colonies, rather than an increase in the population. The results of the 2003 survey are similar to those from the 1982-85 census (i.e. 100 -120 pairs) and suggest that the roseate tern population in Nova Scotia is relatively stable (Table 1; also see Whittam 1998).

The distribution of this population has, however, changed considerably during the last 20 years. For example, surveys from 1982-85 suggest that most roseates were concentrated on Sable Island (10-20 pairs), Tusket Island (15-20 pairs) and The Brothers (55-60 pairs; Kirkham \& Nettleship 1985). By 1995, however, roseates were virtually absent from both Tusket and Sable Islands (Table 1) and in 2003, all but one pair of roseates in Nova Scotia nested on either Country Island or The Brothers (Table 1).

The long-term census data indicate that the roseate tern population in Nova Scotia has been relatively stable. With the exception of The Brothers, however, their distribution in the province has been more variable ( ). In some cases the reasons for colony abandonment are known (e.g. Country Island, see below) while in others it is not obvious (e.g. Grassy Island; Table I). Whatever the reason, shifts of this type make roseates difficult to monitor and suggest that regular censuses should include all suitable breeding habitat. 


\section{Predator Management and Tern Restoration on Country Island, Nova Scotia}

\section{Introduction}

Country Island is a 19 ha island located in Guysborough County $\left(45\left(06^{\prime} \mathrm{N}\right.\right.$; $61\left(32^{\prime} \mathrm{W}\right.$; Fig 1 ) and is the site of a mixed colony of roseate, common and arctic terns. Roseate terns were discovered on Country Island in 1987 and by 1995, it was the location of one of the largest roseate tern colonies in Nova Scotia (see Table I for details). Until 1998, it also supported 20 pairs of great black-backed gulls (Larus marinus), 60-90 pairs of herring gulls (L. argentatus), two pairs of American crows (Corvus brachyrhynchos) and one pair of Northern ravens (C. corax).

In 1996, the tern colony on Country Island suffered heavy predation from corvids and gulls that resulted in nearly complete breeding failure for the 45 pairs of roseate, 130 pairs of common and 330 pairs of arctic terns nesting on the island (Whittam \& Leonard 1999). A year later, only one pair of roseate terns and half the common and arctic terns returned to the island. A tern restoration program using non-lethal predator control was, therefore, initiated in 1998 in an attempt to reduce predation on the island and encourage the return of breeding terns. Here we describe the results of the restoration program by reporting on the numbers and some measures of breeding success for roseate terns nesting on the island before $(1996,1997)$ and after (1998-2002) predator control.

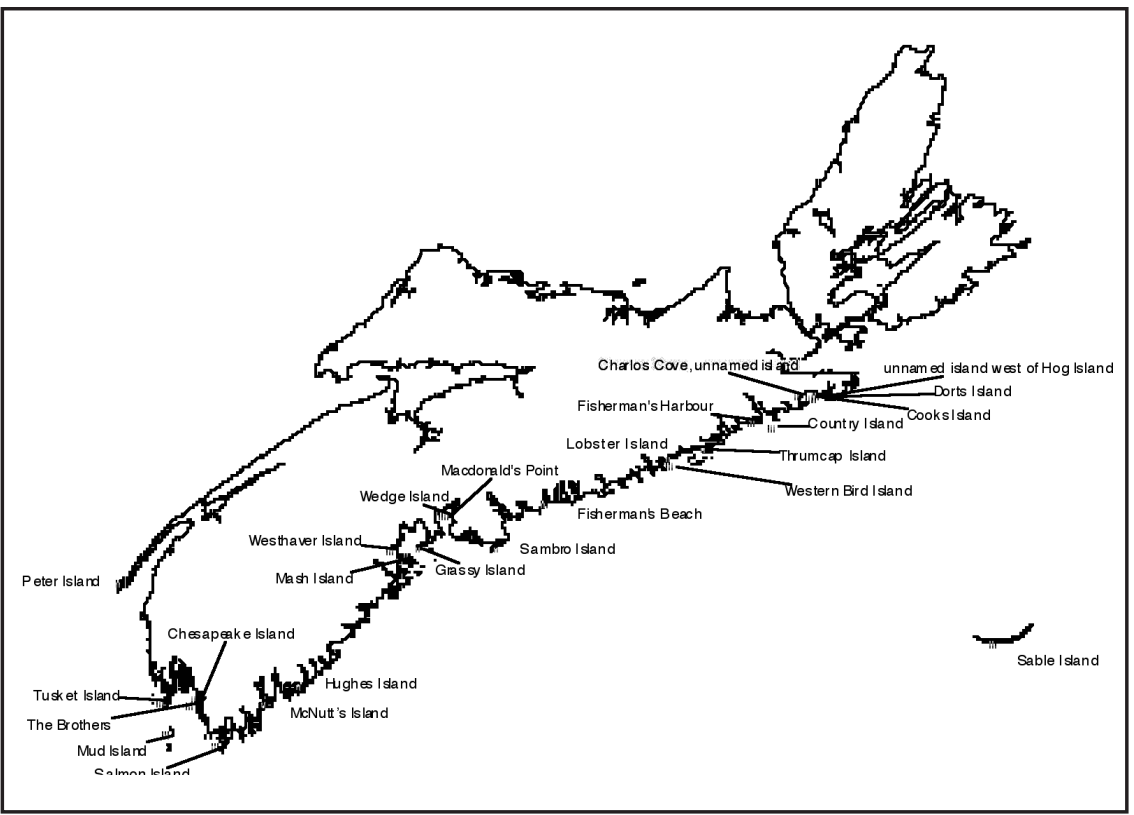

Fig 1 Locations of roseate tern colonies in Nova Scotia occupied at least once between 1982 and 2003 (Whittam 1999, Boyne 2003). 


\section{Methods}

Predator control and observations:

Before terns arrived, we dispersed adult gulls from the island by firing noisemakers every two hours (1998) or when gulls were loafing on the island (1999 - 2002). Once terns returned to the island, noisemakers were used only when gulls were present. We destroyed all gull and corvid nests discovered during our twice weekly searches.

We conducted daily observations of the tern colony between 0600-0800, 12001400 and 1800-2000 and identified each predator entering the colony and whether it took a tern egg or chick.

Roseate tern numbers and reproductive success:

We located tern nests during regular searches of the colony and marked each nest with wooden tongue depressors. We determined the species of tern attending each nest during observations of the colony. A subset of roseate nests was checked approximately every five days to determine clutch size, hatching success and nest fate. We considered an egg to have hatched if a chick was observed at the nest; unhatched if the egg had not hatched within 30 days of being laid; and disappeared, presumed depredated, if the egg could not be found. We determined the fate of chicks during our colony observations by observing feedings at each nest until the end of the dependent period. We considered chicks to have disappeared/ fate unknown if a chick or carcass could not be found after at least two, two-hour observation periods and subsequent searches of the nesting territory, died if a carcass was found and fledged if chicks were observed up to 20 days post-hatch. Our measure of the number of fledglings will be conservative, because the "disappeared" category includes chicks that were taken by predators and died of exposure, but also includes chicks that survived, but moved away from the colony and were not re-sighted.

\section{Results}

\section{Predator control:}

One hundred pairs of gulls bred on the island before predator control began in 1998, however, none have nested successfully since the control program began. The number of nesting attempts by gulls has decreased since control was initiated (1998: 19, 1999: 11, 2000: 3, 2001: 4, 2002: 3).

Corvids have also not bred successfully on the island since the initiation of the control program, although one pair of ravens and one family of up to five crows have attempted to nest on the island annually. The ravens have made one nesting attempt each year, since the control program began, except for 2002. In years when they did nest, they abandoned the island within 24 hours of the destruction of their nest. The crows, on the other hand, have made multiple nesting attempts/year, although the number of attempts has decreased following control (1998: 9, 1999-2002: 2 each year). Unlike the ravens, the crows continue to frequent the island throughout the tern nesting period.

Finally, the number of tern eggs and chicks of all species lost to predation has steadily decreased following predator control (Table 2), as have the number of predator intrusions and the number of successful intrusions in which the predator took an egg or chick (Fig 2).

Roseate tern numbers and reproductive success:

With the exception of 2001, the number of roseate terns breeding on Country Island has increased since the control program was initiated in 1998. In fact, in 2000 the total number of roseate nests exceeded the pre-abandonment numbers (Table 3). In 2001 
Table 2 Colony size (pairs of all tern species), total number of observation hours and number of adults, eggs, and chicks of all tern species taken by corvids, great black-backed gulls and herring gulls on Country Island, before $(1996,1997)$ and after (1998-2002) the initiation of the predator control program.

\begin{tabular}{lllllll}
\hline Predator species & Year & $\begin{array}{l}\text { Hours of } \\
\text { Observation }\end{array}$ & $\begin{array}{l}\text { Colony } \\
\text { Size }\end{array}$ & Adults & Eggs & Chicks \\
\hline Corvid & 1996 & 236 & 505 & 0 & - & 0 \\
Before: & 1997 & 319 & 221 & 0 & 48 & 0 \\
After: & 1998 & 258.5 & 340 & 0 & 2 & 0 \\
& 1999 & 126.5 & 568 & 0 & 0 & 0 \\
& 2000 & 138 & 957 & 0 & 1 & 0 \\
& 2001 & 80 & 811 & 0 & 0 & 0 \\
& 2002 & 84 & 969 & 0 & 0 & 0 \\
Great black-backed gull & & & & & & \\
Before: & 1996 & 236 & 505 & 2 & 1 & 69 \\
After: & 1997 & 319 & 221 & 0 & 7 & 19 \\
& 1998 & 258.5 & 340 & 1 & $3 *$ & 14 \\
& 1999 & 126.5 & 568 & 0 & 0 & 3 \\
& 2000 & 138 & 957 & 0 & 0 & 32 \\
& 2001 & 80 & 811 & 0 & 0 & 3 \\
Herring gull & 2002 & 84 & 969 & 0 & 0 & 5 \\
Before: & & & & & & \\
After: & 1996 & 236 & 505 & 0 & 0 & 124 \\
& 1997 & 319 & 221 & 0 & 2 & 34 \\
& 1998 & 258.5 & 340 & 0 & 0 & 13 \\
& 1999 & 126.5 & 568 & 0 & 0 & 0 \\
& 2000 & 138 & 957 & 0 & 0 & 0 \\
& 2001 & 80 & 811 & 0 & 0 & 0 \\
& 2002 & 84 & 969 & 0 & 0 & 0 \\
\hline
\end{tabular}

* may have been eggs or chicks

only a single pair of roseate terns attempted to nest, despite high numbers of common and arctic terns breeding on the island that year. The reason for this sudden decline is unclear, but appears to have been temporary, as 41 pairs of roseates bred on Country Island in 2002 (Chisholm et al. 2002; Table 3).

Our measures of the number of chicks surviving to fledging (Table 3 ) should be treated with some caution. Measuring roseate fledging success on Country Island has been problematic because chicks often move away from the main colony and are never resighted. Although some of the chicks that disappear have undoubtedly died, some will have survived. Thus, our estimates of the number of chicks surviving to fledging are likely conservative.

\section{Discussion}

The tern restoration program on Country Island has been successful in reducing the number of predators and increasing the number of terns of all species breeding on the island. In general, productivity has also increased following predator management, with common and arctic terns going from complete breeding failure before predator 


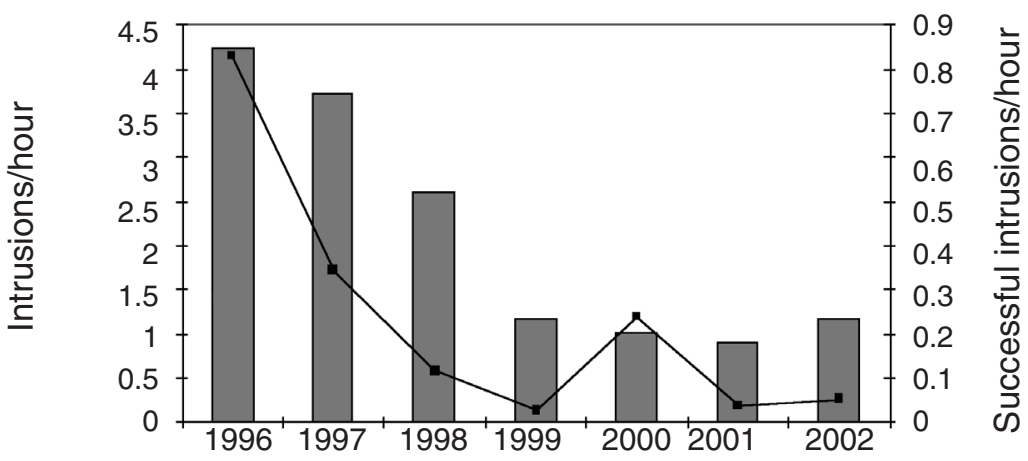

Fig 2 Mean number of predator intrusions (bars) and successful predator intrusions (an egg or chick taken, line) per hour of observation before $(1996,1997)$ and after (1998-2002) predator control.

control (1996), to an average of 1.41 and 1.08 chicks/nest, respectively, in the years following control (1998-2002). Although roseate tern productivity has been more difficult to measure (see above), it has presumably also increased with the decrease in predation pressure.

Non-lethal gull control is considered to be time consuming, logistically difficult and slow to produce results (Thomas 1972). The immediate success of the program on Country Island is likely due to the relatively small number of predators resident on the island before control began (Smith et al. 2000) and to the speed with which the program was implemented (Kress 1997). Two non-lethal gull control programs have also been recently initiated on the Isle of Shoals, New Hampshire (Deluca 2001) and on Penikese Island, Massachusetts (Nisbet 2001). They, too, appear to be experiencing early success - an effect that may be enhanced by a decrease in the number of gulls, particularly herring gulls, breeding in eastern North America (Chapdelaine 1995, Mawhinney et al. 1999, Boyne et al. 2001, Boyne \& Hudson 2002). Although non-lethal control programs require ongoing management to prevent the return of predators (Blokpoel et al. 1997), our results suggest that non-lethal control may be an effective method for managing predators at some seabird colonies.

Predator management appears to be extremely effective in reducing predation and increasing tern reproductive success. Indeed, predator control is considered necessary for the survival of the northeastern population of roseate terns (Nisbet 1981). One potential limitation of these control programs, however, is that when breeding areas are managed for predators the site draws in birds from unmanaged colonies. This tends to concentrate populations into a few, large colonies which then make a larger portion of the population vulnerable to chance events. The benefits of control will generally outweigh these risks, but managers must be vigilant to both anthropocentric and environmental hazards that could put these large colonies at risk.

Although predation is the main factor limiting productivity of roseate terns in Nova Scotia, other factors may also influence reproductive success. For example, roseate terns are susceptible to human disturbance early in the breeding cycle (Nisbet \& Drury 1972), so breeding colonies on or near the mainland are particularly vulnerable. Management of offshore islands for predators may, however, draw these birds to safer breeding habitat (see above). If not, then inshore colonies should be marked with signs advising the public to avoid disturbance to the area during the breeding season. 
Table 3 Fate of roseate tern eggs and chicks on Country Island before $(1996,1997)$ and after $(1998,1999,2000)$ predator control. Total number of roseate tern nests, number of nests monitored to determine fate of eggs and chicks, total number of eggs laid, number that disappeared, number unhatched, mean hatching success (eggs hatched/nest), number of chicks, number that disappeared (includes chicks that were depredated, died of exposure and carcass not recovered, and chicks that survived, but moved away from the colony and were not re-sighted), number dead (carcass recovered), and number fledged on Country Island (adapted from Jensen et al. 2000, Smith et al. 2000, Chisholm et al. 2002).

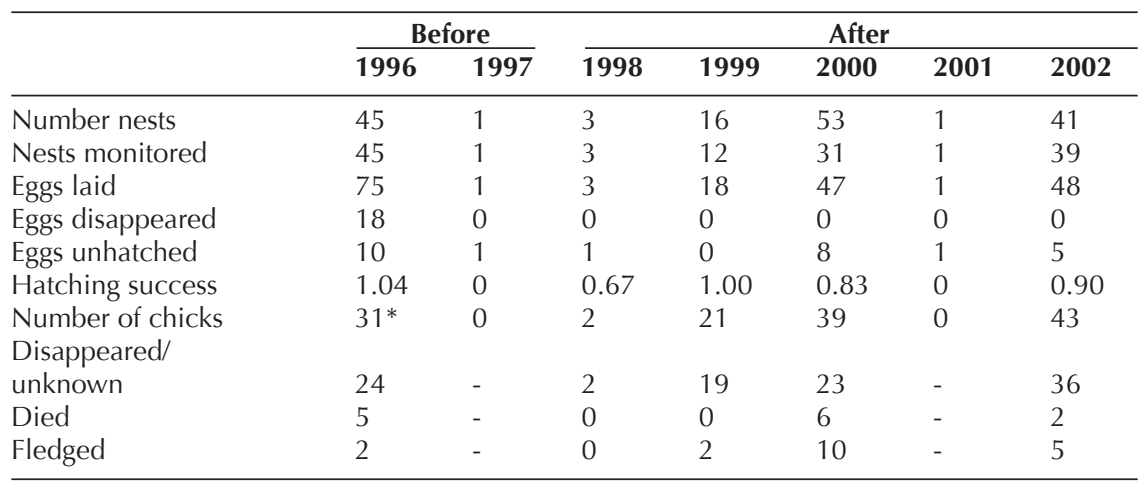

* chicks were followed from 24 nests only

In conclusion, most of Canada's endangered roseate terns breed in Nova Scotia. Much of the management effort for this species should, therefore, be directed toward colonies in this province. Current predator control programs appear successful, but management and monitoring of tern breeding colonies must be ongoing to ensure that populations remain stable, or potentially increase.

\section{Acknowledgements}

We thank Corina Brdar, Sarah Chisholm, Tara Gibson, Maia Jensen, Alayna Kruger, Colleen Martin, Darla Saunders, Sherri Seward, Tasha Smith, Julie Paquet, and Becky Whittam for their excellent assistance on all aspects of this work. A special thanks to Becky Whittam for her input into this study, particularly during the early days. Aerial surveys were co-ordinated by Pam Mills. Nova Scotia Department of Natural Resources staff conducted ground surveys in 1995, and Dedreic Grecian and Jason Beukens assisted with ground surveys in 1999 and 2003, respectively. We also thank Diane Amirault, Pam Mills, Ted D'Eon and the Manthorne family for their continued help and support with this project and World Wildlife Fund, Canada, Environment Canada - Canadian Wildlife Service, Nova Scotia Department of Natural Resources, Environment Canada Science Horizons Youth Internship Program, Important Bird Area Community Action Fund and NSERC for financial assistance. 


\section{References}

Blokpoel H, Tessier GD, Andress RA (1997) Successful restoration of the Ice Island common tern colony requires on-going control of Ring-billed Gulls. Colon Waterbirds 20:98-101

Boates S (1995) ( Nova Scotia Department of Natural Resources, Kentville, NS). Unpubished data

Boyne A (1999) (Canadian Wildlife Service, Environment Canada, Dartmouth, NS). Unpublished data.

Boyne A (2003) (Canadian Wildlife Service, Environment Canada, Dartmouth, NS). Unpublished data.

Boyne AW, Grecian D, Hudson J (2001) Census of terns and other colonial waterbirds in Prince Edward Island - 1999. Tech Rep Ser 372. Canadian Wildlife Service, Environment Canada, Atlantic Region, Dartmouth, NS

Boyne AW, Hudson JK (2002) Census of terns and other colonial waterbirds along the Gulf of St. Lawrence coast of New Brunswick - 2000. Tech Rep Ser 397. Canadian Wildlife Service, Environment Canada, Atlantic Region, Dartmouth, NS

Chapdelaine G (1995) Fourteenth census of seabird populations in the sanctuaries of the north shore of the Gulf of St. Lawrence, 1993. Can Field-Nat 109:220-226

Deluca D (2001) (Audubon Society of New Hampshire, Concord, NH). Personal communication

D'Eon TC (1997) Tern report 1997: Lobster Bay - Southwest Nova Scotia. http://fox. nstn.ca/ deonted/tern97.html.

D'Eon TC (2000) Tern report 2000: Lobster Bay - Southwest Nova Scotia. http://fox. nstn.ca/ deonted/tern00.html.

Gochfeld M, Burger J, Nisbet ICT (1998) Roseate tern (Sterna dougallii). In: Poole A, Gill F (eds) The birds of North America 370. The Birds of North America Inc, Philadelphia, PA

Jensen M, Smith T, Boyne A, Gibson T (2000) Country Island tern restoration project: annual report. Canadian Wildlife Service, Environment Canada, Dartmouth, NS

Kirkham IR, Nettleship DN (1985) Status of the roseate tern Sterna dougalliit (Montagu) in Canada. Committee on the Status of Endangered Wildlife in Canada, Canadian Wildlife Service, Environment Canada, Ottawa

Kress SW (1997) Using animal behavior for conservation: case studies in seabird restoration from the Maine Coast, USA. J Yamashina Inst Ornithol 29:1-26

Kress SW, Weinstein EH, Nisbet ICT (1983) The status of tern populations in northeastern United States and adjacent Canada. Colon Waterbirds 6:84-106

Lock AR (1971) Census of seabirds nesting in Nova Scotia, May 18 to June 30, 1971. Canadian Wildlife Service, Environment Canada, Dartmouth, NS

Mawhinney K, Diamond T, Kehoe P, Benjamin N (1999) Status and productivity of common eiders in relation to the status of great black-backed gulls and herring gulls in the southern Bay of Fundy and northern Gulf of Maine. Waterbirds 22:253-262

Nisbet ICT (1981) Biological characteristics of the roseate tern Sterna dougallii. United States Fish and Wildlife Service, Office of Endangered Species, Newton Corner, MA

Nisbet ICT (2001) (Nisbet and Co. North Falmouth, Mass.). Personal communication

Nisbet ICT, Drury WH (1972) Measuring breeding success in common and roseate terns. Bird-Banding 43:97-106

Smith TE, Leonard ML, Jensen M, Boyne A (2000) Restoration of roseate terns (Sterna dougallii) to Country Island, Nova Scotia. Report to the Endangered Species Recovery Fund, World Wildlife Fund Canada, Toronto, ON 
Thomas GJ (1972) A review of gull damage and management methods at nature reserves. Biol Conserv 4:117-127

Tufts RW (1962) The birds of Nova Scotia. Nova Scotia Museum, Halifax, NS

Whittam RM (1998) Updated status report on the roseate tern, Sterna dougallii. Committee on the Status of Endangered Wildlife in Canada, Canadian Wildlife Service, Environment Canada, Ottawa

Whittam RM, Leonard ML (1999) Predation and breeding success in roseate terns (Sterna dougallii). Can J Zool 77:851-856 